\title{
Ahdistunut kansakunta
}

\author{
Elise Nykänen \& Riikka Rossi (toim.): Suomalaiset ahdistukset. Kansallinen omakuva ja \\ kielteiset tunteet. Joutsen / Svanen. Erikoisjulkaisuja 4. Helsingin yliopisto: Suomalai- \\ nen klassikkokirjasto, Helsingin yliopiston suomalais-ugrilainen ja pohjoismainen \\ osasto, 2020, 164 s. https://journal.fi/joutsen-svanen-erikois-special/issue/view/5483
}

Tunnetutkimus on jo pitkään ollut osa kirjallisuudentutkimusta. Nyt ansioituneet tutkijat ovat koonneet antologian verran artikkeleita, joissa keskitytään kielteisiin tunteisiin kaunokirjallisuuden henkilöhahmoissa, kerronnassa, tyyleissä ja tunne-efekteissä. Innoittajana on muuan muassa toiminut epämukaviin tunteisiin tarttuneen Sianne Ngain kiinnostava Ugly Feelings (2005). Teosta jäsentää ajatus kansakunnasta tunneyhteisönä, jota kielteiset tunteet sekä rakentavat että hajottavat.

Antologian fokuksessa on alaotsikkonsa mukaisesti kansallinen omakuva, ja artikkeleissa tarkennetaan etenkin kriisiaikoina ilmestyneisiin tai niitä käsitteleviin teoksiin. Topeliuksen runo "Septembernatten" (1867) ja Tavaststjernan romaani Hårda tider (1891) ovat Riikka Rossin artikkelin kohteina, ja molemmat ottavat tahoillaan kantaa nälkää kärsivään kansaosaan. Ensin mainittu teos osoittautuu helppoa empatiaa huokuvaksi, jälkimmäinen on kriittisempi ja siksi tuottaa vaikeampaa empatiaa vaatiessaan lukijaa tunnistamaan moraalisen ristiriitaisuutensa.

Rossin artikkeli on hyvä avaus antologialle osoittaessaan, että teosten esittämät, kuvaamat ja käsittelemät tunteet sekä niiden aiheuttamat tunnevaikutukset ovat mutkikas verkosto. Se ilmenee myös Viola Parente-Čapkován artikkelissa L. Onervan novellista "Manja Pavlovna" (1909) ja Yksinäisiä-romaanista (1917). Muista poiketen englanniksi kirjoitettu artikkeli on lisäksi kirjan ainoa, jossa keskitytään naiskirjailijaan. Tutkija analysoi Onervan melodramaattisen tyylin ryydittämiä tunnevoimaisia tapoja ilmaista venäläisyyttä ja Venäjää. Rasismilta ei vältytä. Teos antautuu kuitenkin myös ironiselle lukutavalle ja osoittautuu lopulta kriittiseksi rasistista ja muuta oppositioajattelua kohtaan.

William Reddylta peräisin oleva tunnehallinnon käsite korostaa yhteisöjen tapaa normittaa tunteita ja havainnollistuu varsinkin Anna Hollstenin artikkelissa. Hollsten tarkastelee sota-ajan runoutta tunnekäytäntöinä, jotka vaikuttavat ja joiden avulla vaikutetaan ihmisten tunnetilaan. Esimerkiksi Eila Kivikk'ahon (1942) vapaarytminen runo osoittaa tunnehallinnon rajoituksiin ja niiden seurauksiin, toisaalta Yrjö Jylhän Kïrastuli (1941) saattoi toimia terapeuttisena ja toi lohtua aikalaisille. Unto Kupiaisen kauhukuvaukset ja heroismia arvostelevat runot eivät menneet sensuurista läpi, mutta tarjoavat myöhemmässä katsannossa aitiopaikan tunteiden kirjoon. Yksityisiä tunteita 
ei välttämättä voi erottaa kansallisista, kuten Hollsten korostaa, ja se tulee poikkeusoloissa hyvin esille.

Marko Tapion Aapo Heiskasen viikatetanssi (1956) on Elise Nykäsen artikkelin aiheena. Sen epäluotettava päähenkilö hajoavine mielineen tuottaa menneisyydestä useita versioita. Teos on itsensä tiedostava ironinen romaani, joka parodioi myös aiempaa kirjallista traditiota, mutta siinä on kuitenkin ahdistunut perusvire. Nykäsen luennan mukaan monitunnelmaisuus luo mahdollisuuden useampiin lukijapositioihin. Yhtäältä ironia ja metafiktio tuottavat tunnetason etäisyyttä ja huvittuneisuuttakin. Toisaalta ironian käyttö problematisoituu, sillä halu nauraa kärsimykselle voi tuntua pahalta.

Pirjo Lyytikäinen keskittyy ihanteellisen kansallismaiseman vastakuviin. Juhani Ahon lastussa "Kurjalan rannalla" (1891) naturalismin keinot valjastetaan kansallisten tuntojen kuvaamiseen. Marko Tapio taas luo Lyytikäisen mukaan kaksiosaisessa Arktisessa hysteriassaan (1967 ja 1968) vastakuvan Pohjantähden positiiviselle kansankuvalle. Tapion kertoja on varsin epämukava esimerkiksi silloin, kun hän pohtii sodan hyötyjä ja välttämättömyyttä ihmiskunnalle. Vastakuvia näyttää lisäksi koko artikkeliantologian ainoa uudempi kaunokirjallinen teos, Matias Riikosen romaani Suuri fuuga (2017). Kokeellinen dystopia ammentaa nostalgisia kansallisen identiteetin kuvia, jotka ovat peräisin niin Runebergiltä kuin Gösta Sundqvistiltakin. Maailmanlopun allegoria tuottaa Lyytikäisen luennassa vaikeasti artikuloitavan typertyneen mielentilan.

Antologian kaksi viimeistä artikkelia käsittelevät ääriajattelijoita. Antti Ahmala tarkastelee Pentti Linkolan esseistiikkaa ja muita kirjoituksia. Niistä käy ilmi, että Linkola oli paitsi syväekologi, myös kauneudenpalvoja ja luonnonihailija. Etenkin modernisaatiota kohtaan hän koki kielteisiä tunteita. Nykyaika on kurjaa, ja Linkolan mielestä monet kaipaavat entisen kaltaista, ekologisesti ja inhimillisesti kestävää elämänmuotoa. Ahmalan tulkinnan mukaan Linkola pyrkii aktivoimaan mielialoja, jotka ajaisivat meidän pois mukavasta mutta ahdistavasta vankilastastamme.

Ääriajattelua edustaa myös Jussi Halla-ahon blogi, jota pöyhivät Tuija Saresma ja Urho Tulonen. Perussuomalaisten kärkihahmolle länsimainen kulttuuri näyttäytyy uhanalaisena ja aiheuttaa siksi ahdistusta. Käy ilmi, että Halla-ahon blogi ei ole - toisin kuin joku saattaa luulla - sananvapauden pyhättö vaan ihmisten tunnereaktioita hyödyntävä vallankäytön keino. Poliitikko pyrkii järkeilemällä osoittamaan näkökantansa oikeaksi, mutta saa vaivoin peiteltyä affektiivisen otteen, joka kuitenkin useimmiten piiloutuu hänen käyttämänsä ironian sisään. Tutkijoiden mukaan viha ei olekaan välttämättä tällaisten verkkoyhteisöjen alkuperäinen käyttövoima, vaan se voi olla retorisesti nostatettu tunne, joksi vähemmän hyväksytyt tunteet tai muut kokemukset, esimerkiksi epävarmuus, huolestuneisuus tai ahdistuneisuus pyritään kanavoimaan. "Toiset" feminisoidaan ja emotionalisoidaan.

Suomalaisten ahdistusten keskittyminen juuri kielteisiin tunteisiin on tervetullut valinta. Antologiaan valittu näkökulma pysyy kansakunnan kertomisen 
affektiivisessa ulottuvuudessa, joka kytkeytyy "ylirajaisiin tunnerakenteisiin ja niitä kielentävään modernismin poetiikkaan", kuten johdannossa todetaan. Ylirajaisuus viittaa teoksessa etenkin laji- ja tyylikysymyksiin. Usein juuri ironia osoittautuu keinoksi kritisoida modernisaatiota.

Milloin kirjallisuuden esittämistä tai lukijaan vaikuttavista kielteisistä tunteista sitten tulee osa kansallista omakuvaa? Kohdeteosten valinta jätti mietteliääksi, eikä johdanto-osuus tuo siihen valaistusta. Esimerkiksi Maria Jotunin ja Marja-Liisa Vartion teoksilla olisi kielteisten tunteiden ja kansakunnan suhteen runsain mitoin tarjottavaa. Nykyromaaneissa taas ylirajaisuus laventaa näkökulmia kansallisesta (oma)kuvasta ja siihen nivoutuvista tunteista muun muassa maahanmuuttajataustaisten kirjoittajien teoksissa. Suosittu historiallinen nykyromaani on usein kriittisellä kannalla menneisyydestä tehtyjen tulkintojen suhteen, eikä sekään ohita epämukavia tunteita. Nykyrunoissa puolestaan ilmastoahdistus on valtavirtaa, ja niissä kansallinen nivoutuu väistämättä globaaliin. Epäilemättä kielteisten tunteiden tutkimusta - kansakunnan näkökulmasta tai sitä ilman - tarvitaan vielä lisää.

Siru Kainulainen 